\title{
Temperature-dependence of the TRIP effect in a metastable austenitic stainless steel
}

\author{
V. V. Stolyarov ${ }^{\dagger, 1,2}$, K. A. Padmanabhan ${ }^{3}$, V.F. Terentyev ${ }^{4}$ \\ ${ }^{1}$ Mechanical Engineering Research Institute, RAS, 4 Kharitonievsky St., Moscow, 101990, Russia \\ ${ }^{2}$ National Research Nuclear University MEPhI, Kashirskoe shosse 31, Moscow, 115409, Russia \\ ${ }^{3}$ Department of Mechanical Engineering, College of Engineering Guindy, Anna University, Chennai, 600025, India \\ ${ }^{4}$ Institute of Metallurgy and Materials Science, RAS,, 49/3 Leninsky Av., Moscow, 119991, Russia

\section{†vlstol@mail.ru}

The effect of test temperature in the range $20-400^{\circ} \mathrm{C}$ on mechanical properties under quasi-static tension and phase composition in metastable austenite-martensite TRIP steel in the form of a sheet of $0.3 \mathrm{~mm}$ thickness is investigated. Here strength and ductility increases are caused by austenite to martensite phase transformation. As supplied, the steel contained $65 \%$ martensite and 35\% austenite. Due to tensile testing at room temperature, the amount of martensite increases to $84 \%$, which leads to high strength $(1600 \mathrm{MPa})$ and a relative elongation to failure of $20 \%$. There is no neck formation. With an increase in test temperature from room temperature to $400^{\circ} \mathrm{C}$, the strength characteristics, especially yield strength, sharply decreases to $700 \mathrm{MPa}$ and below. At the same time, the elongation to failure decreases by an order of magnitude to $2 \%$. Above a test temperature of $100^{\circ} \mathrm{C}$, deformation localization begins, the length of the yield plateau on the stress-strain curve decreases, and then disappears. X-ray structural analysis of the sample surface after tension showed that the volume fraction of martensite in the microstructure decreases from $84 \%$ at $20^{\circ} \mathrm{C}$ to $42 \%$ at $400^{\circ} \mathrm{C}$. With an increase in temperature in the range of $20-400^{\circ} \mathrm{C}$ the influence of the TRIP effect on the mechanical properties of austenitic steel gradually decreases, and the direct transformation of austenite to martensite eventually changes to the reverse transformation of martensite to austenite. It is assumed that the embrittlement of steel with increasing temperature is associated with inhomogeneous martensite decomposition and precipitation of fine carbides at grain boundaries.

Keywords: austenite-martensite steel, TRIP effect, tensile test temperature, mechanical properties, phase composition.

УДК: 669: 539.4.015

\section{Температурная зависимость ТРИП эффекта в метастабильной аустенитной нержавеющей стали}

\author{
Столяров В. В. ${ }^{\dagger 1,2}$, Padmanabhan K. А. ${ }^{3}$, Терентьев В. $Ф .{ }^{4}$ \\ †vlstol@mail.ru
${ }^{1}$ Институт машиноведения РАН, ул. М. Харитоньевский, 4, Москва,101990, Россия
${ }^{2}$ Национальный исследовательский ядерный университет МИФИ, Каширское ш., 31, Москва, 115409, Россия
${ }^{3}$ Департамент механики, Инженерный колледж Ганди, Университет Анны, Ченнай, 600025, Индия
${ }^{4}$ Институт металлургии и материаловедения РАН, Ленинский пр-т 49/3, Москва, 119334, Россия

\begin{abstract}
Исследовано влияние температуры испытания в интервале температур $20-400^{\circ} \mathrm{C}$ на механические свойства при квазистатическом растяжении и фазовый состав в метастабильной аустенитно-мартенситной ТРИП стали в форме листа толщиной 0.3 мм, в которой повышенные прочность и пластичность обусловлены прямым фазовым превращением аустенита в мартенсит. В состоянии поставки сталь содержала 65\% мартенсита и $35 \%$ аустенита. В процессе растяжения при комнатной температуре количество мартенсита увеличивается до 84\%, что приводит к высоким значениям прочности (1600 МПа) и относительного удлинения до разрушения (20\%), отсутствует шейкообразование. Однако с повышением температуры испытаний от комнатной до $400^{\circ} \mathrm{C}$ предел прочности и особенно предел текучести, резко уменьшаются до 700 МПа и ниже. Одновременно с этим на порядок уменьшается относительное удлинение, до $2 \%$. Выше температуры испытания $100^{\circ} \mathrm{C}$ начинается локализация деформации, площадка текучести на кривой напряжение-деформация уменьшается, а затем исчезает. Рентгеноструктурный анализ поверхности образцов
\end{abstract}


после растяжения показал, что объемная доля мартенсита в микроструктуре уменьшается с $84 \%$ при $20^{\circ} \mathrm{C}$ до $42 \%$ при $400^{\circ} \mathrm{C}$. С повышением температуры в интервале $20-400^{\circ} \mathrm{C}$ влияние ТРИП эффекта на механические свойства аустенитной стали постепенно уменьшается, а прямое превращение аустенита в мартенсит изменяется на обратное превращение мартенсита в аустенит. Предполагается, что охрупчивание стали с повышением температуры связано с неоднородным распадом мартенсита и выделением мелких карбидов на границах зерен.

Ключевые слова: аустенитно-мартенситная сталь, ТРИП эффект, температура испытаний, механические свойства, фазовый состав.

\section{Introduction}

Strips/sheets of complex-alloyed metastable steels, in which martensitic transformation is induced by plasticity (TRIP), have long been used as a material for structural parts of cars and helicopters [1]. A large number of external and internal factors affect the martensitic transformation and, consequently, the TRIP effect, which simultaneously increases the strength and ductility of such steels [2-4]. A significant number of studies have been carried out on the effect of chemical composition, deformation and heat treatment, structure refinement, formation of gradient structure on the phase transformation and the TRIP effect. Thus, in [5] it is shown that $\mathrm{Al}$ additions increase the balance of total elongation and tensile strength due to the refined ferrite structure and morphology of martensite. The authors of [6] found that chemical inhomogeneity of austenite after critical annealing determines the final microstructural constituents and the sensitivity of the final product to TRIP heat treatment. Finally, the strong grain refinement of austenite [7] and the formation of a gradient structure [8] can significantly increase either strength or ductility. A recent study included the use of acoustic emission to study the kinetics of sheet tensile transformation at room temperature and $373 \mathrm{~K}$ [9].

Despite numerous articles on the TRIP effect, there are practically no experimental data on the temperature dependence of the mechanical properties of these steels, and the TRIP effect is studied at room temperature. There is only one article in which the temperature dependence of the TRIP effect was investigated, but it was carried out with a decrease in the test temperature [10]. As a rule, in this case, the $M_{\mathrm{s}}$ temperature (transformation start without stress) of residual austenite is below room temperature and differs from the $M_{\varsigma}^{\sigma}$ temperature (under stress). An exception is the article [11] in which the authors, based on the data on the behavior of yield point and the associated temperature-depenendent tensile strength, concluded that it is possible to determine the $M_{S}^{\sigma}$ temperature at the moment of transition from smooth flow to discontinuous flow. Martensitic transformation leads to load relaxation and to a decrease in the yield stress. Thus, in a series of temperature-lowering tests, the yield point and its corresponding $M_{S}^{\sigma}$ temperature were first detected.

This study is an attempt to improve understanding of the TRIP effect by studying the effect of test temperature on the mechanical behavior under uniaxial tension and the phase composition of the metastable austenite-martensite TRIP steel.

\section{Experimental: Material and Methods}

The material selected is a TRIP steel strip of thickness $0.3 \mathrm{~mm}$. Its chemical composition is (wt.\%): C 0.25; Cr 14.5-16.0; Ni 4.8-5.8; Mo 2.7-3.2; $\mathrm{Mn} \leq 1.0$; $\mathrm{Si} \leq 0.6$;
$\mathrm{N}_{2} 0.03-0.07 ; \mathrm{S} \leq 0.01 ; \mathrm{P} \leq 0.015 ; \mathrm{Fe}-$ balance. The initial microstructure is a mixture of deformed martensite $(65 \%)$ and work hardened austenite (35\%) (Fig. 1). It should be noted at this stage that the term "deformed martensite" ( $\alpha$-phase) may in reality be a mixture of the two bcc phases of ferrite and martensite, which cannot be differentiated easily due to the similarity in their lattice type and lattice parameters. $\mathrm{X}$-ray analysis was done using a Rigaku Ultima diffractometer, with $\mathrm{Cu}-\mathrm{K}_{\alpha}$-radiation.

Tensile tests in the temperature range of $20-400^{\circ} \mathrm{C}$ and a deformation rate of $1 \mathrm{~mm} \cdot \mathrm{min}^{-1}$ (which corresponds to an initial strain rate of $5.6 \cdot 10^{-4} \mathrm{~s}^{-1}$ for the present tensile specimens (Fig. 2)) were performed on a horizontal IR508 testing machine.

Heating was done with hot air from technical dryer GHG 660 LCD Professional (Bosch) which hasthepossibility ofstepwisetemperature controlin the range of $50-660^{\circ} \mathrm{C}$ and the direction of air with a special nozzle. Control of temperature with accuracy $\pm 5^{\circ} \mathrm{C}$ was ensured by a chromel-alumel thermocouple attached to the middle of the gauge length of the test specimen. As is well known, tests done at strain rates less than $10 \mathrm{~s}^{-1}$ are known as quasi-static tensile tests [12]. Microstructures of test sample fracture surfaces were investigated by SEM VEGAIISB (TESCAN).

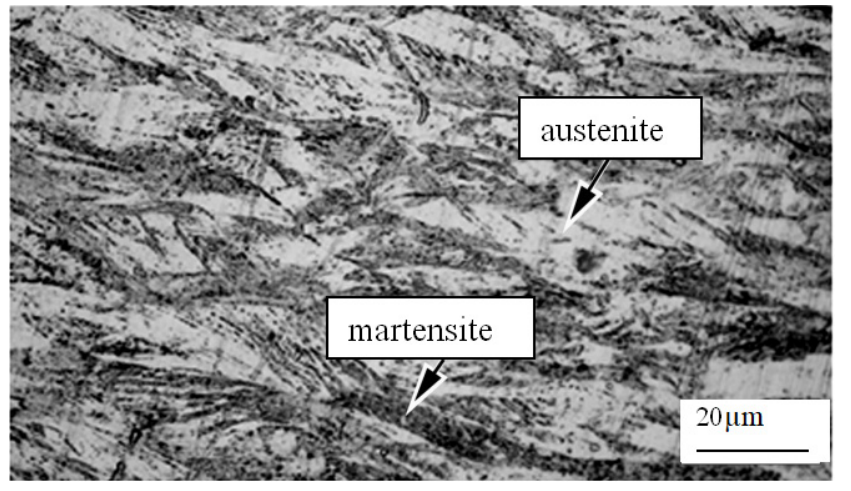

Fig. 1. Optical micrograph of the initial state of the austenitemartensite steel.

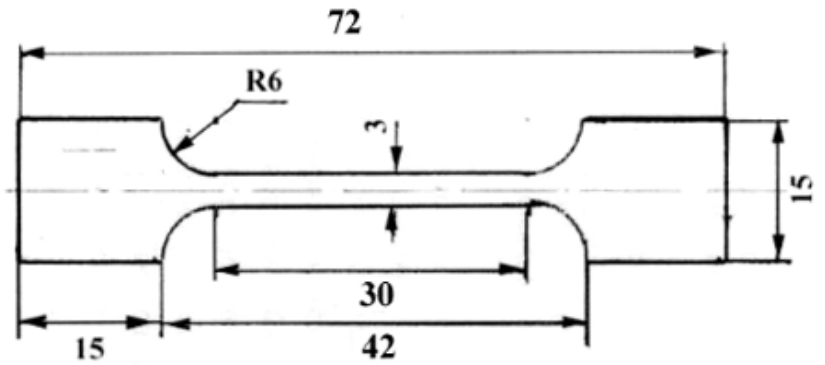

Fig. 2. Tensile test sample (all dimensions in $\mathrm{mm}$ ). 


\section{Results and discussion}

In Fig. 3 the engineering stress-strain curves in the temperature range of $20-200^{\circ} \mathrm{C}$ are presented (for completeness, curve 5 is reproduced from our earlier publication [13]). At a test temperature of $20^{\circ} \mathrm{C}$ (curve 1), beyond the yield point, as in a previous report, weak deformation hardening is observed [12]. The stress-strain curves at 20 and $50^{\circ} \mathrm{C}$ are very similar, but in the stress-strain curve for $50^{\circ} \mathrm{C}$, deformation hardening is less evident (curve 2), which is suggestive of normal behavior with a rise in temperature. It is known from literature that such mechanical behavior (large plateau length, weak strain hardening and absence of neck formation) at room temperature in metastable steels is due to the reverse deformation transformation of martensite to austenite, the so-called TRIP effect [2]. Increasing the test temperature to $100^{\circ} \mathrm{C}$ and above changes the nature of the stress-strain curves significantly. On the stress-strain curves at test temperatures of $100-200^{\circ} \mathrm{C}$, a sharp yield point is absent, but there is a region of strong deformation hardening, accompanied by a noticeable decrease in the yield strength and the elongation to failure (curves 3,4). The behavior of the curves with increasing test temperature clearly indicates a decrease in the stability of the structure and phase composition that is consistent with the earlier report [10]. Such an appearance of the stress-strain curves is typical of austenitic steels and evidently at enhanced test temperatures the structure becomes increasingly austenitic due to a reverse martensite transformation. Decreasing elongation to fracture with increasing temperature is an anomalous effect and needs explanation (see below). It was shown earlier [14] that the introduction of a DC current during tensile testing also leads to a similar change in the nature of the stress-strain curves (curve 5).

A comparison of curves 4 and 5, both of which correspond to the same test temperature of $200^{\circ} \mathrm{C}$, reveals that in the curve 5 the flow stress and the elongation to fracture are somewhat reduced compared with the curve 4 . This could be due to either (i) a difference in the temperature distribution in the tensile specimens due to a change in the heating technique (industrial dryer heating vs. direct current heating), or (ii) a greater amount of austenite formation due the additional contribution to the reverse phase transformation (martensite to austenite) from the electroplastic effect present in the latter. (A detailed study on this aspect is presently underway.) It is interesting that both the strength and the elongation to fracture decrease with increasing austenite formation during

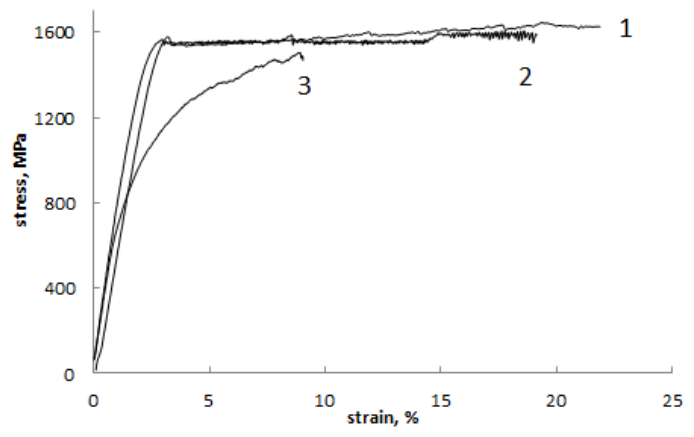

a plastic deformation and this is accounted for below.

In Fig. 4 the dependence of ultimate tensile strength (UTS) and elongation to fracture on test temperature is displayed. Due to the reverse transformation of martensite to austenite, there is a sharp decrease in the UTS value with an increase in the test temperature. It is well known that martensite is a stronger/harder phase than austenite. However, in this case there is also a decrease in the elongation to failure. Intuitively, one would expect austenite to be more ductile than martensite. But it must be kept in mind that here the partial transformation of martensite to austenite is concurrent with plastic deformation and due to the heterogeneous nature of the phase transformation, stress concentrations are expected to develop in the regions undergoing phase transformation (particularly at the interfaces) and, as observed, this will decrease the overall ductility of the specimen. A supporting piece of evidence comes from the work of Shin et al. [14], who working on SS304 steel, of composition close to the present one, have concluded that in their steel martensite formation during deformation ceased above the $M_{d}$ temperature of $\sim 50^{\circ} \mathrm{C}$.

In the present alloy, the relative elongation decreases from $20 \%$ at $20^{\circ} \mathrm{C}$ to $2 \%$ at $200^{\circ} \mathrm{C}$ and remains almost at the same level till $400^{\circ} \mathrm{C}$. In [15], using samples of metastable austenitic steel of composition (wt.\%) $0.3 \mathrm{C}$; $9 \mathrm{Cr} ; 8 \mathrm{Ni} ; 3 \mathrm{Mn}$; Fe balance, it is shown that even at a test temperature of $100^{\circ} \mathrm{C}$, the elongation is only $3 \%$. Such a sharp reduction in ductility at elevated test temperatures in metastable austenitic steels, e.g., austenite-martensite TRIP-steel, in analogy with the process of temper brittleness of the first order [2], can be related mostly to the non-uniform decomposition of the supersaturated solid solution of carbon in the $\alpha^{\prime}$-phase. Transformation at these

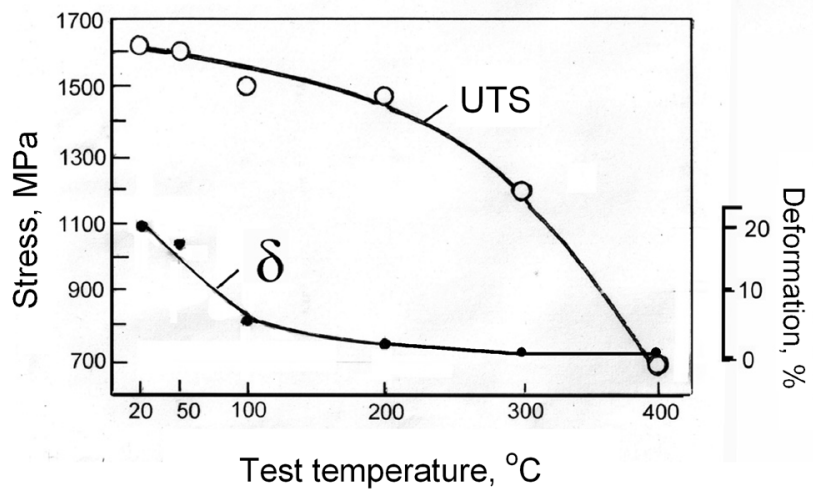

Fig. 4 Effect of test temperature on the ultimate tensile strength and elongation of TRIP steel.

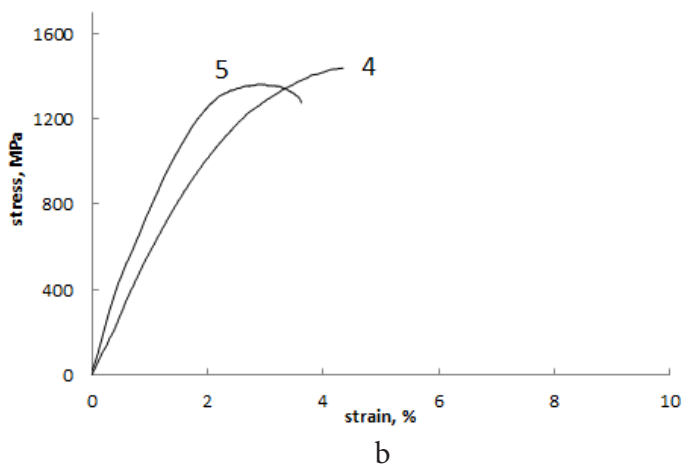

Fig. 3. Engineering stress-strain curves for TRIP steel heated to: (industrial dryer) $-20^{\circ} \mathrm{C}(1), 50^{\circ} \mathrm{C}(2), 100^{\circ} \mathrm{C}$ (3) (a); (industrial dryer) $200^{\circ} \mathrm{C}(4)$, (direct current) $-200^{\circ} \mathrm{C}(5)(\mathrm{b})$. 
temperatures is more dominant at the grain boundaries, with cementite type of carbide formation.

This results in a sharp difference between the strength of the boundary regions of the grains and the grain interiors. It would appear, therefore, that in this case the grain boundary regions are the regions of stress concentration that are responsible for the observed drastic decrease in the ductility of the material.

Quantitative changes in the phase ratios of the tested samples with the test temperature and the corresponding X-ray images are presented in Figs. 5, 6. Evidently, X-ray analysis helps identify only the lattice type. Thus, the results indicate only the quantity of bcc structure, without a distinction between martensite and ferrite. Indeed, it has been argued that it is not at all easy to distinguish between the two bcc phases because their lattice constants are extremely close. However, [17] has pointed out that with deformation, the peaks of martensite $\left(a^{\prime}\right)$, highly saturated with carbon, will shift away from that of ferrite ( $\alpha$ ), which practically contains no carbon (hence much softer), and after some deformation it should be possible to distinguish between the two phases very clearly. Such an effort to distinguish between the two bcc phases will be undertaken in a future study. For the present, following other workers, all the changes in the phase of bcc structure is traced to deformed martensite $\left(\alpha^{\prime}\right)$.

With an increase in test temperature, the amount of deformed martensite in TRIP steel drops sharply from $84 \%$ at $20^{\circ} \mathrm{C}$ to $42 \%$ at $400^{\circ} \mathrm{C}$ (Fig. 5) by a partial reverse transformation of deformed martensite to austenite. In addition, due to oxidation, at $400^{\circ} \mathrm{C} \mathrm{Fe}_{2} \mathrm{O}_{3}$ formation is present on the surface layers of the steel specimen. In the initial state (i.e., before the tension tests) there was $65 \%$ deformed martensite in the steel structure. Tension at room temperature leads to an increase in the bcc $\left(a^{\prime}\right)$ phase to $84 \%$. Tensile testing at $400^{\circ} \mathrm{C}$ leads to a decrease in the bcc phase to $42 \%$. It is not easy to conclude that the deformed martensite seen is single phase because on slow cooling the ferrite phase ( $\alpha$ ) could also have separated. However, as [17] has shown that ferrite forms during slow cooling only after tempering at $600^{\circ} \mathrm{C}$, it has been assumed here that in the test temperature range of $100-400^{\circ} \mathrm{C}$ the phase transformation involved is a partial reverse martensite to austenite transformation.

The fact that the amount of martensite present after tensile tests at temperatures of 20 and $50^{\circ} \mathrm{C}$ is greater than that observed in the untested, starting material indicates that up to $50^{\circ} \mathrm{C}$ the

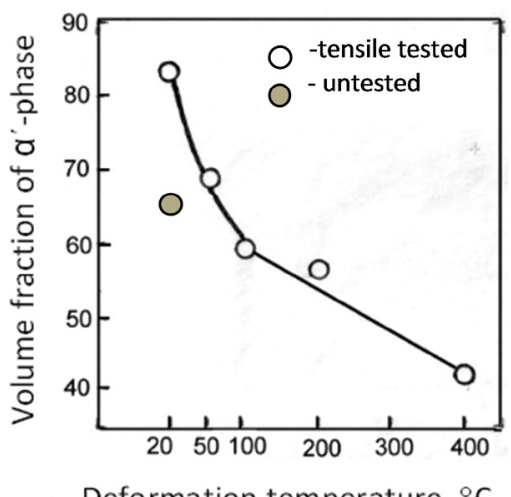

- Deformation temperature, ${ }^{\circ} \mathrm{C}$

Fig. 5. Quantitative changes in the volume fraction of $\alpha^{\prime}-$ phase as a function of the test temperature.

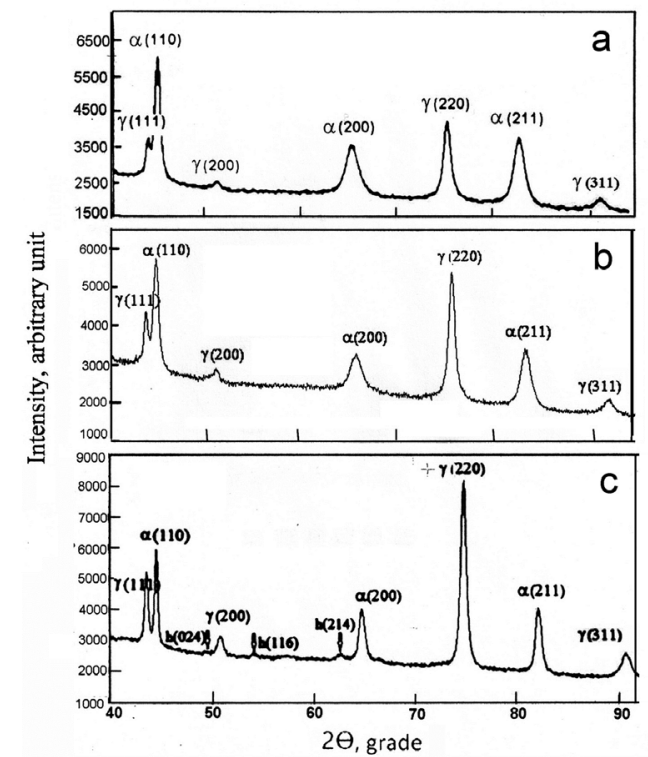

Fig. 6. X-ray diffraction patterns of TRIP steel tested at $50^{\circ} \mathrm{C}$ (a), $200^{\circ} \mathrm{C}(\mathrm{b}), 400^{\circ} \mathrm{C}(\mathrm{c})$.

TRIP effect (i.e., the formation of additional martensite from austenite as a result of deformation) is present in this steel. This is in agreement with the findings of [6], who have also shown that room temperature tensile test of an as-received steel sheet leads to additional martensite formation.

Finally, it is noted that in this steel of $0.25 \% \mathrm{C}$, in the tensile stress-strain curves a sharp yield point ceases to exist at $100^{\circ} \mathrm{C}$ and above. In steels both interstitial carbon and carbon present as carbides influence the presence or absence of both the yield point and the yield point elongation. The latter two features become less significant with increasing temperature, strain rate and carbon content. It has been shown very clearly [18-20] that such a view is valid in the range up to $0.3 \% \mathrm{C}$ and temperatures between 100 and $256^{\circ} \mathrm{C}$. It is also well known that in a material like TRIP steel, which is heavily alloyed, the diffusivity of carbon is significantly altered by the presence the heavier substitutional alloying elements. Therefore, more pointed comments would not be in order without a detailed study of the yield point phenomenon.

SEM study of fractures showed that on the entire sample surface after tension at room temperature, areas of homogeneous viscous fracture are observed mainly by separation with a dimple size of 3-5 $\mu \mathrm{m}$ (Fig. $7 \mathrm{a}$ ). With an increase in the test temperature, areas of viscous fracture by shear with a larger dimple size appear on the fracture surface, the volume fraction of which for a temperature of $200^{\circ} \mathrm{C}$ can be more than $50 \%$ (Fig. $7 \mathrm{~b}$ ). Generally, this type of fracture is typical for high-temperature deformation of steels [21]. Since the volume fraction of the $\left(\alpha^{\prime}\right)$ phase decreases with increasing temperature (Fig. 5) it can be assumed that the separation and shear mechanism acts, respectively, for the martensitic and austenitic phase.

Thus, the microstructure, phase composition and properties of the investigated TRIP steel under tension depend on the mechanism of martensite transformation which with increasing deformation temperature changes from predominantly phase transformation $\mathrm{M} \rightarrow \mathrm{A}$ at relatively low temperatures to completely reverse decomposition into ferrite-cementite mixture $\mathrm{M} \rightarrow \mathrm{F}+\mathrm{C}$. 


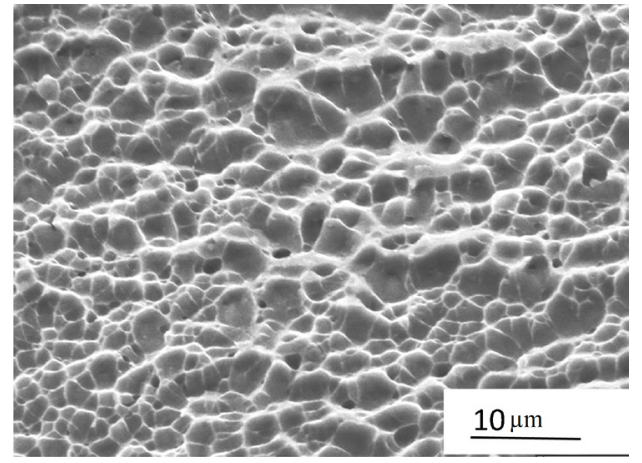

a

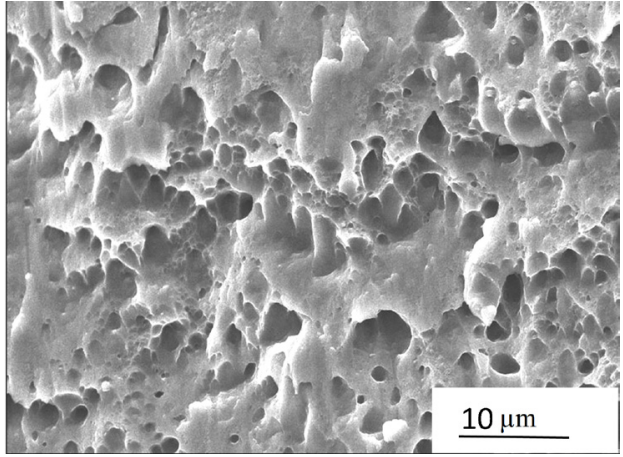

$\mathrm{b}$

Fig. 7. SEM micrograph of fracture surface in TRIP steel subjected to tension at: $20^{\circ} \mathrm{C}(\mathrm{a}) ; 200^{\circ} \mathrm{C}(\mathrm{b})$.

\section{Conclusions}

1. With increasing tensile test temperature in the range of $20-400^{\circ} \mathrm{C}$, in sheet austenite-martensite TRIP steel there is a sharp decrease in the ultimate tensile strength from $1600 \mathrm{MPa}$ to $700 \mathrm{MPa}$ and the elongation to failure drops from 20 to $2 \%$. These results are associated primarily with the process of reverse transformation of martensite to austenite (i.e., there is a decrease in the TRIP effect with increasing temperature, which eventually becomes a partial reverse transformation of martensite to austenite).

2. The amount of deformation-induced martensite in the structure of TRIP steel decreases from $84 \%$ after a tensile test at $20^{\circ} \mathrm{C}$ to $42 \%$ at $400^{\circ} \mathrm{C}$. Stabilization of austenite leads to the disappearance of the yield point on the stress-strain curve and the replacement of the separation deformation mechanism by the shear deformation mechanism.

3. The above observations have been accounted for qualitatively using experimental evidence.

Acknowledgements. This work was supported by the Competitiveness Program of the National Research Nuclear University MEPhI (Moscow Engineering Physics Institute), contract with the Ministry of Education and Science of the Russian Federation No. 02. A03.21.0005, 27.08.2013, RFBR grant 16-58-48001 of Russia and of the Department of Science and Technology, Government of India (No. DST/INT/RFBR/I DIR/P-04/2016).

\section{References}

1. V. Zackay, E. Parker, D. Fahr, R. Bush. Trans. ASM. 60, 252 (1967).

2. N. Fonstein. Advanced High Strength Sheet Steels. Springer 396 p. (2015). DOI: 10.1007/978-3-319-19165-2

3. J.Chiang, B. Lawrence., J.D. Boyd, A.K. Pilkey. Mater. Sci. \& Eng. A. 528, 4516 (2011). DOI: 10.1016/j.msea.2011.02.032

4. H.J. Jun, S.H. Park, S.D. Choi, C.G. Park. Mater. Sci.\& Eng. A. 379, 204 (2004). DOI: 10.1016/j.msea.2004.01.029

5. O.A. Girina, N.M. Fonstein, Developments in Sheet Products for Automotive Applications Organized by J.R. Fekete and R. Pradhan. Materials Science \& Technology. 65 (January, 2005).
6. G. Azizi, H. Mirzadeh, M. H. Parsa, Mater.Sci.Eng. A. 639, 402 (2015). DOI: $10.1016 /$ j.msea.2015.05.045

7. M. Shirdel, H. Mirzadeh, M.H. Parsa, Mater. Charact. 103, $150 \quad$ (2015). DOI: 10.1016/j.matchar.2015.03.031

8. X.L. Wu, M.X. Yang, F.P. Yuan, L. Chen, Y.T. Zhu. Acta Mater. 112, 337 (2016). DOI: 10.1016/j.actamat.2016.04.045

9. A. Vinogradov, A. Lazarev, M. Linderov, A. Weidner, H. Biermann. Acta Mater. 61 (7), 2434 (2013). DOI: $10.1016 /$ j.actamat.2013.01.016

10. D. Bhandarkar, V.F. Zackay, E. R. Parker. Lawrence Berkeley National Laboratory. LBNL Report \#: LBL-125 (1972)

11. A. Vasilakos, K. Papamantellos, G. Haidemenopoulos, W. Bleck. Steel Research 70 (11), 466 (1999).

12. V. F. Terentyev, D. V. Prosvirnin., A. K. Slizov, L. I. Kobeleva, A. Yu. Marchenkov, A.A. Ashmarin, V.P. Sirotinkin. Russian Metallurgy (Metally). 4, 389 (2018). DOI: 10.1134/S0036029518040195

13. V.V. Stolyarov, E.A. Klyatskina, V.F. Terentyev. Letters on materials. 6 (4), 355 (2016). DOI: 10.22226/2410-3535-2016-4-355-359

14. H.C. Shin, T. K. Ha, Y.W. Chang. Scr. Mater. 45 (7), 823 (2001). DOI: 10.1016/S1359-6462(01)01101-0

15. D. Fahr. Metallurgical Transactions. 2, 188 (1971).

16. S. Harjo, N. Tscuchida, J. Abe, W. Gong. Sci Rep. 7, 15149 (2017) . DOI: 10.1038/s41598-017-15252-5

17. V.F. Terentyev, A. A. Ashmarin, E. N. Blinova, D. D. Titov, V. M. Blinov, A. K. Mucous, T. G. Sevalneva. Deformation and fracture of materials 6, 20 (2018).

18. D. H. Johnson. Luders bands in RPV Steel: PhD thesis. Cranfield University, U.K. (2012) 243 p.

19. A.K. Slizov. Osobennosti mechanicheskogo povedeniya listovoy metastabilnoy austenitno-martensitnoy stali s uchetom proyavleniya trip effecta: Dissertacija na soiskanie stepeni kandidata tehnicheskih nauk. Moscow (2018) 111 p. (in Russian) [А.К. Слизов. Особенности механического поведения листовой метастабильной аустенитно-мартенситной стали с учетом проявления трипэффекта: дисс. канд. техн. наук. Москва (2018) 111 с.]

20. S. Gao, Y. Bai, R. Zheng, Y. Tian, W. Mao, A. Shibata, N. Tsuji, Scr. Mater. 159 28-32 (2019). DOI: 10.1016/j.scriptamat.2018.09.007

21. M.A. Filippov, V.S. Litvinov, Y.R. Nemirovsky. Steels with metastable austenite. Moscow, Metallurgy. (1988) 256 p. 